\title{
Philosophy and Kabbalah. Elia Benamozegh (1823-1900), a Progressive/Traditional Thinker
}

\author{
Alessandro Guetta
}

check for

updates

Citation: Guetta, Alessandro. 2021. Philosophy and Kabbalah. Elia Benamozegh (1823-1900), a Progressive/Traditional Thinker. Religions 12: 625. https://doi.org/ $10.3390 /$ rel12080625

Academic Editor: Richard A. Cohen

Received: 24 June 2021

Accepted: 8 August 2021

Published: 10 August 2021

Publisher's Note: MDPI stays neutral with regard to jurisdictional claims in published maps and institutional affiliations.

Copyright: (C) 2021 by the author. Licensee MDPI, Basel, Switzerland. This article is an open access article distributed under the terms and conditions of the Creative Commons Attribution (CC BY) license (https:// creativecommons.org/licenses/by/ $4.0 /)$.
Institut National des Langues et Civilisations Orientales, 75007 Paris, France; alessandro.guetta@gmail.com

\begin{abstract}
Elia Benamozegh (born—1823 in Livorno and died-1900 in Livorno)—philosopher, biblical exegete, teacher at the Rabbinical College-was an original and fruitful thinker. At a time when the Jewish kabbalah, or esoteric tradition, was considered by the protagonists of Jewish studies as the result of an era of intellectual and religious decadence, Benamozegh indicated it to be the authentic theology of Judaism. In numerous works of varying nature, in Italian, French and Hebrew, the kabbalah is studied by comparing it with the thought of Spinoza and with German idealism (Hegel in particular), and, at a later stage, also with positivism and evolutionism. Benamozegh formulated a pluralistic religious philosophy open to progress by constantly referring to the first phase of Vico's historicist philosophy and above all to the work of Vincenzo Gioberti. We can read this philosophy as an original and consistent response to the challenges of Modern, secularized thought.
\end{abstract}

Keywords: Judaism; philosophy; kabbalah

\section{Elia Benamozegh, His Life and Cultural Context}

Elia Benamozegh (born-1823 in Livorno and died-1900 in Livorno) is probably the last representative of the long Italian Jewish philosophical tradition of rabbinic inspiration, and also one of the rare modern Jewish philosophers of religion that doesn't stem from the German or Polish-Lithuanian area. The son of Moroccan parents, he was trained in Jewish culture by his uncle Yehuda Coriat, who initiated him into the knowledge of the Zohar, the main text of the kabbalah, the esoteric Jewish doctrine.

Benamozegh was a young preacher at the synagogue of the important Community in Livorno, and later a judge in ritual matters and a theology teacher in the local rabbinical College. Self taught in nonreligious subjects, Benamozegh was particularly attracted to European philosophical thought-in particular Spinoza, Hegel and his contemporaries Comte and Darwin. Among the Italian philosophers, his main-and largely acknowledgedsources of inspiration were Giambattista Vico (1688-1744), for his theory of the language as the depository of a civilization, and Vincenzo Gioberti (1801-1852), for many important issues such as the dialectic of particular/universal and of revelation/progress.

Although in total connection with the philosophical tendencies of his time, Benamozegh was, however, original, not only for the systematic reference to traditional Jewish, biblical and rabbinic sources, but above all for his kabbalistic education. It should be recalled that the kabbalah, in addition to representing a thought historically in antithesis or in competition with philosophy, was generally discredited in the 19th century throughout Jewish European scholarly circles, which considered it, at best, as having recent, not ancient origins, or, at worst, as dogmatic irrationalism tinged with superstition, produced by the obscurantist culture typical of the "ghettos era". ${ }^{1}$ Against this commonly shared orientation, Benamozegh considered the kabbalah to be the true Jewish theology, the very ancient dogmatic nucleus which completed a religion that was otherwise mainly performative, i.e., linked to practices and devoid of any clear theoretical (theological) foundation.

The cultural education of Benamozegh's North African origin also constitutes a peculiarity within European culture, not only the Jewish. It can be said that the work of 
Elia Benamozegh (which means "Berber") constitutes the transition from a traditional intellectual world far from Western "modernity", to that of a Europe in full effervescence; it will therefore be possible to read his texts as a translation, not only linguistic but also and above all conceptual, from the theology of the Zohar assimilated by a Maghrebi master to the main European philosophical movements of the time: idealism in its various manifestations, successively, positivism (Auguste Comte) and evolutionism (Charles Darwin). This peculiar "way to modernity" is correctly emphasized by Clémence Boulouque in her recent monograph, whose title is, significantly, Another Modernity. ${ }^{2}$

\section{Benamozegh's Main Works}

Benamozegh was a prolific author. He wrote in Italian, Hebrew and French, a language he chose in order to reach out to a wider audience.

Em la-miqra (see note 1) ("Matrix of the text"), a Hebrew commentary on the Torah (Pentateuch), is a particularly original work in which classical exegesis and kabbalah on the one hand, and linguistics, philosophy, history of religions and archeology on the other, are used to comprehend the text. Omnipresent in this work are the early works by Giambattista Vico, who sought in the Latin language the manifestation of ancient knowledge, specific to Italic civilization. Benamozegh does the same for Hebrew: a considerable number of Hebrew words are read as implicit containers of the ancient Hebrew doctrine, which he considers to be the kabbalah. The study of linguistics, particularly etymology, is, therefore, a means to understand the speculative tradition. The systematic association between "sacred" and "profane", the juxtaposition of kabbalah and the history of religions, and of the "holy masters" of the Talmud and the revered texts of Jewish tradition to authors such as the Catholic Giambattista Vico and Vincenzo Gioberti (and many others, often called chakhamim gedolim, great scholars), sparked outrage among Aleppo rabbis-who excommunicated the author-and the Jerusalem rabbis, who condemned the text.

Morale juive et morale chrétienne (see note 2) is an affirmation of rabbinic Jewish morality against the current vision of a materialistic Judaism, unable to rise to the ethical and spiritual sphere of Christianity. Actually, the moral apologia-which is conducted with precision and with an abundance of textual references-gives rise to a comparative analysis of the theological type, Benamozegh's privileged field. The same type of analysis is found in the book that originally constituted the first part of Morale juive et morale chrétienne, which remained unpublished until very recently, L'origine des dogmes chrétiens. ${ }^{3}$ Here, the author examines the founding texts of Christianity in the light of the kabbalah: the thesis is put forth whereby it was the misguided understanding of the esoteric Jewish doctrine in some decisive conceptual articulations which, together with an erroneous social destination (the whole of humanity instead of a limited audience of initiated readers, as the delicate esoteric doctrine should have required) that gave rise to the Christian religion, with its positive aspects and its insufficiencies.

The Teologia dogmatica e apologetica is undoubtedly Benamozegh's most accomplished work from a philosophical point of view. The author only published the first part, Dio; and the ensuing parts were published posthumously. It is, above all, on this Teologia that we will draw to articulate the essential lines of Benamozegh's thought.

Israël et l'humanité,, also posthumous, deals with the relationship between the Jewish religion and the world. Developing one of the typical themes of nineteenth century Jewish thought, i.e., the particularism/universalism dialectic, the author participates in the European debate on the crisis of religion by proposing kabbalistic Judaism as an inspiration and a philosophical/religious orientation for the future of Humanity: in this hardly known version, writes Benamozegh, Judaism is not, but rather has a universal religion, which integrates at the same time the "Oriental" notion of unity and the "Western" notion of multiplicity; Israel is seen as a priest of a family of peoples of different cultures and attitudes, all united in the common worship of the only God (Morselli and Maestri 2017).

These are the main works. Worth highlighting, among the numerous others, are some remarkable texts in Hebrew that defend the kabbalah and argue on the antiquity, if not of its 
main texts, certainly of the doctrine: the Storia degli Esseni, ${ }^{6}$ which aims to establish a line of continuity between this ascetic Jewish sect and the cabbalists; and a long essay on Spinoza et la kabbale ${ }^{7}$ which aims to demonstrate how Spinoza's philosophy, and indirectly the whole of European idealism that was inspired by it, originated from an incorrect reading of kabbalistic theology; in this sense, it is complementary and symmetrical with L'origine des dogmes chrétiens. Spinoza deified the world, Christianity brought the divine to the earthly: both ignore the distinction between the world in its material and in its ideal configurations, as does the kabbalistic theology.

Numerous other writings in Italian, Hebrew and French, of a philological or philosophical nature, complete the work of the scholar from Livorno.

\section{The Transcendence and Presence of God}

Benamozegh's thought cannot be fully understood if his profound and intense religiosity is not taken into account. God is not, for him, the object of abstract speculations, a logical necessity; rather, it is a powerful presence, even if not fully understandable for mankind. Precisely being beyond human grasp, the transcendence (or superintelligibility, in Benamozegh's expression) of God increases its importance. The best demonstration of God's existence lies in the impossibility of any definitive demonstration, and its irreducibility to human knowledge opens up to mystery, which is a strong presence, not a vague indefiniteness. All the demonstrations that follow are sustained by this feeling of an unattainable Entity, not of an absence, which is at the origin and at the center of the entire created world.

The philosophical-religious dimension of Benamozegh's thought is clearly recognizable in the following quote from Teologia, which concludes a critical argument on some central elements of the thought of Spinoza and Hegel:

We will not say what that titan of Hegel said to his disciples: «In the lesson to come we will create God». In saying so, he sank to the degree of fetishist [ ... ] Rather, we will do like Moses, who in the fleeting moment in which God passed before him, quickly bowed his head-and worshipped. ${ }^{8}$

God is conceived as the absolute unity, the point of a circumference from which its rays emanate and to which they return; like the knot of the created world, which supports and unifies by being both transcendent and, to a certain extent, immanent. Pantheism, seen as "the formidable error of our times", does not distinguish between the world and God, while between the two there is a substantial and infinite difference, even if the world has something divine in itself.

Religious thought should not be, as in Maimonides, a negative theology consisting more of a series of negations than of affirmations due to the fear of formulating definitions of God inspired by the human dimension. According to Benamozegh, a "legitimate" anthropomorphism exists, and we can speak of the effects of God in human terms, because the effects retain something of their cause. Therefore, up to a certain point, we can speak of God, whose attributes are knowable and definable through their effects; and going back, cause by cause, we attain God, the Primary cause, the "Type" of origin from whom everything is inspired and according to whom everything is shaped, even if in an imperfect and limited manner. ${ }^{9}$ Hence the critique of Kant's theory of the absolute impossibility to know God. As Boulouque writes,

The problem is not that Judaism denied the gap between the human and the divine but rather that Kant denied humanity the knowledge of how to bridge the gap, including through revelation. ${ }^{10}$

This also recalls the idea of Analogia entis by the Catholic philosophers Erich Przywara and Edith Stein, who obviously did not know Benamozegh and referred to Thomas Aquinas: mankind is infinitely far from God, yet it is shaped on him and find in itself the idea of him. ${ }^{11}$ 
In the history of the kabbalah, the discussion on the nature of the sefiroth, or divine emanations, has revolved around their understanding as the essence (mahuth) of God (or rather of what can be called "divinity", because God itself is absolutely transcendent) or as its tools (kelim), through which the world is produced and governed. Implicit in classifying to one or the other category is the question of the possibilities of mankind to know levels of reality that are superior to its own world, and possibly to act on them. Benamozegh considers both aspects to be true, the knowable world recalls something of the level which is only indicated and not fully known. The "chain of beings" model is also explicitly mentioned by him.

Humanity as a whole can take the path that separates it from God, because the divine imprint is present in the world, but this way is infinite. Between God and the world there is no identity - therefore pantheism is rejected-nor absolute separation - therefore theism and the absolute transcendence of God are rejected. Benamozegh's model is explicitly emanationist, but his sources are kabbalistic. He encounters Platonism and Neoplatonism, which allow him to give a philosophical terminology to a conception absorbed by reading the Zohar and, to a lesser extent, kabbalistic literature. ${ }^{12}$ This is the reason why Benamozegh attributed the following definitions to the four "worlds" of kabbalah, atziluth (emanation), beriyah (creation), yetzirah (formation), 'asiyah (realization): (1) True Attributes (which reveal God in themselves), (2) Laws or categories (which reveal God as the cause or universal law), (3) Ideas (God as an intelligible model of created things), (4) Bodies (God as center of the forces that give life and movement to matter).

\section{The Scientific/Philosophical "Translation" of Kabbalah}

The order and even the arrangement of the ten sefiroth, or divine emanations, can be "translated" into the psychological, physical, moral and social orders in just as many categories. For example, in the psychological and epistemological order:

$$
\text { Entity-The "Me" }
$$

Intuition

Doubt or Denial

Reflection $^{13}$

Order

Science or Affirmation

Reason or Logos

\section{Feeling \\ Sensation ${ }^{14}$}

The names of God that appear in the Torah allude to this double aspect of God, the supernatural and unknowable one, and the manifest and knowable one: the first is Ehyeh, which appears in the first revelation to Moses (Exodus 3:14, Ehyeh asher ehyeh, literally "I will be what I will be"), is appropriate to name this aspect as it appears only once in the Bible and is in the future tense, therefore "inconceivable"; 15 the second is Yah, "in which the Entity already affirms itself and allows itself to be understood". The double aspect of God is also suggested by the four letter name of God, the tetragrammaton, written in one wayunpronounceable - and read in another-intelligible. God is, therefore, simultaneously both Nothing and Being, in which the first term is superior to the second, not inferior as in the Hegelian dialectic-because otherwise there would be a God in the making-but superior. "God is Nothingness in that he is neither a being nor a particular form, but everything in perfect and ineffable unity". 16

At the same time, the formula quoted above, Ehyeh asher ehyeh, "I will be what I will be", presents God as a conjunction, expressed through the relative pronoun, between the infinite Entity (in itself) and the infinite Cause (which opens to the world through its production of effects). "The all-sacrosanct conscience of God is formulated by himself in Ehyeh asher ehyeh: God who thinks — the act of his thought-the object of his thought". ${ }^{17}$

In kabbalistic terminology, this corresponds to the three superior sefiroth, Keter (Crown), Chokhmah (Wisdom) and Binah (Intelligence). The latter, also called "Mother who is above", i.e., origin, is therefore read as an infinite cause, and is distinct from the last sefirah, called 
Malkhuth (Kingdom), also called "Mother who is below", contiguous to the material world. In his interesting and original analysis of Spinoza's philosophy, ${ }^{18}$ Benamozegh attributes the pantheism of the Dutch philosopher, who identifies God with nature, to a misinterpretation of the difficult kabbalistic theology. By interpreting Binah, who is the ideal cause of matter, as if it were Malkhuth, the "interface" between the divine and the earthly world, Spinoza shortened the chain of beings, lowering God to matter. On the other hand, symmetrically and inversely, even the first Christians misunderstood the kabbalah. In Christianity, the descending line that unites the sefiroth Chokhmah, Tifereth (Beauty) and Malkhuth has been mistaken for the triad of the three superior emanations.

The consequence is that nature, the world and time have been reabsorbed into the supernatural and eternal, with the result that the material and historical world has been considered as impure and condemned as such. Rather than seeing the world and history as necessary manifestations of divinity, Christianity condemned them; but in doing so it denied the legitimacy of politics and placed the unattainable sublime morality as the real objective of mankind. Additionally, by denying the world, Christianity left it to the dominion of the devil, thus devoting itself to ethical and political impotence and its direct consequences, that is, extreme asceticism, religious wars and the absurdity of controlling consciences. Christian devotion to the sublime produces "the monster of the Inquisition", whereas Judaism, which considers the world as a manifestation of God, contemplates political opposition and ideological and religious tolerance.

Authentic religious philosophy therefore consists in an attempt that can never been fully implemented: to understand the Entity and its relations with the world. By inscribing the notions and terms of the French and Italian religious idealism of the time onto a kabbalistic scheme, Benamozegh thinks of a relationship between God and the world as an emanatistic type: actually, he often and explicitly agrees with Platonic and neo-Platonic thought. God, in itself and in relations with the world, is described according to a scheme of triads that invert the sense of the Hegelian dialectic: instead of theses and antitheses that give rise to a synthesis, the synthesis (God) is seen at the beginning of the process of creation or emanation, because the less proceeds from the more, the parts from the whole.

\section{Revelation and Progress. The Unfolding of Consciousness}

As we have seen, the first triad is constituted by the articulation between knowerknowledge-knowable referring to God, which actually constitutes a unity. This conception of Aristotelian origin, and developed by medieval thought, is revised by Benamozegh through a slight variation in terminology, which changes its horizon. God is no longer defined as supreme selfknowledge, as in Greek and medieval intellectualistic thought, rather as supreme selfconsciousness. Therefore, the process of emanation constitutes a progressive loss of consciousness and a fall into the unconscious, and the return to the divine center corresponds to a passage from the unconscious to the conscious. By acquiring consciousness, mankind gets closer, infinitely, to God. Medieval intellectualism is, therefore, transformed into a broader dimension: the full discovery of the world and of the self (in all its dimensions) replaces the illumination of the speculative intellect.

Just as the soul of man is the link and point of convergence in a unity, to which multiple sensations, feelings and thoughts refer, so too is God the unity of all consciences, past, present and future ("Conscience, I, Unity"), ${ }^{19}$ an unfolded consciousness in which nothing remains of the unconscious, a dimension of the human world that is constantly in the making. ${ }^{20}$ The collective level replaces the individual search, typical of the medieval period: human history taken as a whole is the history of the progressive passage from the unconscious to consciousness, the conquest of new regions of this last and the growing presence of humanity to itself. The idea is typical of some eminent nineteenth century idealists, such as Ernest Renan, Eduard von Hartmann (author of Philosophy of the unconscious) ${ }^{21}$ and Wilhelm von Humboldt (in the essay The task of the historian), but it had also been formulated—without its typical nineteenth century collective aspect—by some sixteenth 
century (Moshe Cordovero) and even fourteenth century (Ezra of Gerona) kabbalists, who could have inspired Benamozegh.

However, the most direct and explicit influence is that of the Catholic philosopher Vincenzo Gioberti, Benamozegh's main theological reference, who provides him with the conceptual tools to express the ideas absorbed upon studying the Zohar in the language of the European religious philosophy of his time. Benamozegh is undoubtedly indebted to Gioberti for a concept such as "palingenesis", the new birth or future projection of man announced in an intuitive way by the divine revelation, and for the idea of a nation that, by uniting the features of East and West, can aspire to a central role in the future of humanity (Italy for Gioberti, Israel for Benamozegh).

In turn, this philosophical-religious thought, considered as peripheral by the dominant historiography (who reads Gioberti's works today? In which history of Jewish philosophy does the name of Benamozegh appear?) can be seen as the cultural context and proximate cause of other slightly later and far more popular forms of thought. Freud's psychoanalytic theory of the unconscious, and even more so that of Jung with its collective dimension, can be better understood within this philosophical-theological frame of reference, which preceded them by a few decades and certainly (albeit indirectly) inspired them. The necessity to proceed from the sphere of the unconscious to the conscious dimension for therapeutic (Freud) and hermeneutic purposes (Jung) was, in a way, anticipated by these religious thinkers, be they Catholic or Jewish. On the other hand, we can consider that the insistence on the simple unity of the soul and on the intrinsically dynamic nature of the extradivine world, in a certain sense, precede the thought, also slightly later, of Henri Bergson, whose poles are the unity of consciousness and its temporal dimension, the duration.

The human condition is, therefore, a temporal one, and consists of a constant ascent: progress. Yet this optimistic idea of Western modernity, which Benamozegh endorses with enthusiasm, including at a political level (he manifested openly liberal positions in 1848, which led to his censorship by the Grand Ducal authorities), does not have a purely human and historical value. The progress and perfection of humanity are the movement towards something that has always been there, the divine center, intuitively known in an earlier period.

The original intuition, corresponding to prophetic and collective revelation, guides the human journey, which therefore has a compass providing an orientation. The human task consists in developing through reflection what has been known in an intuitive form; human history is the history of an indefinite improvement whose paths have already been traced, and of which we perceive in ourselves potentiality.

Everyone realizes how this revealing faculty of God is the origin of human perfectibility—of progress. Therefore [ ... ] outside the divine, logically there cannot be progress [ ... ] We can see the insanity of those who believe, by banishing God, to serve progress. If there were no Infinity, wouldn't I find it in myself? How would I turn to it?? 22

More precisely, in the prophetic revelation man perceives the future-collective-of the species, and this is how we should interpret the projection of man outside himself in an idealized dimension. Feuerbach had called for the resumption of this projection, considered an illusion, in the human sphere-to reduce theology to anthropology. Benamozegh accepts the idea of projection but does not see it as a simple psychological illusion, but rather as the actual trace of the ideal man, intuited in the past and to which to aspire for the future.

This concept of time is anchored in a clear opposition to relativism and subjectivism. Truth is not changeable, neither in time nor in space. The ways of conceiving it are relative, but its unity is absolute. In his "religious proposal" to humanity (actually, to the Western world) struggling in a crisis of values and in the midst of secularization, Benamozegh invites the consideration of the religious dimension, which implies the recognition of the existence of an absolute, like a horizon constantly present for humanity, even for those who declare themselves atheists or skeptics. 
I believe that man is a progressive being, and not just the individual man, but the species. And precisely for the reason that he is progressive, he has on the one hand the need, on the other the means, of elevating himself to a revealed doctrine, to a Revelation. ${ }^{23}$

\section{A "Jewish Universalism". The Complementarity of Western and Oriental Civilizations}

Indeed, as indicated by the plural number of the Hebrew word God, Elohim, the ways of considering this absolute vary according to peoples (or "races", as they wrote in the 19 th century without any racist dimension) and their respective natures. The idolater, upon closer inspection, adores an aspect of God, like the worshipper of any religion. However, this plural vision is composed, or should ideally be composed, in harmony with what can be defined as the "geniuses" of every nation, to compose the shape of future humanity, united in the worship of God even if not necessarily in the same ways. ${ }^{24}$ Benamozegh's vision is, therefore, both unitary and pluralistic: Judaism does not aspire to become a religion for everyone but has a doctrine to propose to a humanity in search of references. This doctrine is provided precisely by the kabbalah, which contemplates, at the same time, unity, typical of an "Eastern" mentality, and multiplicity, typical of "Western" thought; of both certainty and tolerance, permanence and movement. It should be noted that the kabbalah, from an esoteric doctrine, as it was at its origins, is transformed by Benamozegh into the most complete form of religiosity to be proposed to the whole of humanity.

Incidentally, the use of terms typical of nineteenth century culture can be noted: Benamozegh speaks of history, progress, humanity, peoples endowed with almost essential specificities, species (Darwin is cited and discussed on several occasions). However, he places these notions within a religious, Jewish and cabalistic context. The "Eastern" and "Western" categories, which alternate in the works of the European authors of the time with those of "Semitic" and "Aryan" well before the unleashing of racist ideology, are not seen in opposition or in a relationship of hierarchy-in which, inevitably, Europe was seen as the realization and improvement of the "Semitic" civilization-but as complementary. Benamozegh's vision contemplates the association in the diversity of nations and religions.

The triumphant West, which at the same time is experiencing a profound crisis, should, according to Benamozegh, turn to the East to "orient itself" in the form of discourse (science should not reject poetic thought as primitive) and in its contents (the tendency to the Absolute). The formal side is important because it has a cognitive value. The kabbalah, for example,

sang its dogmas, while Spinoza's philosophy demonstrated them; one is a powerful harmony, an uninterrupted hymn, while the other has produced nothing but a web of definitions, axioms and corollaries: the first revealed thoughts according to the manner of poets, with their liberal tendencies, their impulses and their audaciousness, while the second exposed them as geometers do. ${ }^{25}$

The "poet theologians", however, writes Benamozegh, referring explicitly to Giambattista Vico's New Science, are not representatives of a "primitive" way of thinking, as it was according to the Neapolitan philosopher, but rather of another way of approaching reality. Indeed, contrary to what is thought in a commonly accepted conception of cultural evolution, "mythology" constitutes the most mature phase in the history of Jewish culture, expressed by rabbinical aggadoth, which can represent God in an anthropomorphic way. ${ }^{26}$ The thought that he defines as "oriental" immediately captures

the sudden conversions from the proper to the improper sense of a word, grasping at first glance the entire infinite serie of applications, accessories, ramifications, in which the underlying idea is progressively transferred". ${ }^{27}$

At the same time, discursive thinking, the advancement of science, the historical vision of humanity, and the importance attributed to multiplicity, all these typical traits of "Western" thought, must be kept in mind in the formulation of the human journey; the 
kabbalah, which aspires to the simple unity of God through the necessary multiplicity of his manifestations (in which lies something divine), can represent the doctrine of the future. It is a culture of contiguity ("une forme mitoyenne", as he writes in Israël et l'Humanité), in which the notions of separation and assimilation are present at the same time.

In this way, the two tendencies inherent in man will be respected: the intellectual tendency, towards universal and absolute affirmations, and the political and anthropological tendency, which favors particularism and sees the reality of the multiple as unsurmountable. Like Moses Mendelssohn before him, Samuel David Luzzatto and the Galician philosopher Nachman Krochmal in his time, Hermann Cohen, then Martin Buber (and numerous other Jewish authors) after him, Benamozegh gives a modern justification for the persistence of the people of Israel, insofar as the bearer of a religious (and ethical) tradition indispensable to humanity, in a chorus of nations that contribute-as a whole-to achieving a composite totality. Kabbalistic Judaism, writes Benamozegh, was able to assimilate external tendencies by assimilating them into a harmonious unity. In addition, the history of religions that describes their historical developments and their diversity, far from being in antithesis with theology, can contribute to understand it better.

Nations must not be overcome, contrary to what Christianity professes, rather, they should contribute to a concert as in a prism-that remains ideal. In the humanity of the future, Jews that bear this cabalistic culture, monotheistic and pluralistic at the same time, will be able to have the function of priests.

All this is also supported and discussed through a series of references to medieval rabbinic, kabbalistic and philosophical literatures; for the contemporary reader knowledgeable about the history of European thought, in reverse of Benamozegh's path from kabbalah to philosophy, these terminological and conceptual transpositions can serve to understand the difficult kabbalistic doctrine.

\section{A Problematic Reception}

The complex intellectual personality of Elia Benamozegh did not help his reception. Considered by his students as "the Plato of Italian Judaism", other readers, such as the German historian Abraham Berliner, considered him instead as a great intellect "born under a bad star" - that is, too Maghrebian and "oriental" to make a decisive contribution to the Jewish culture of his time (Guetta 1998, 2009).

The restricted circles of the Italian Semitists of the time, including his pupil David Castelli, distanced themselves from Benamozegh's philological theories, not "scientific" enough because too inspired by a theological vision; not to mention his older contemporary, the linguist and exegete Samuele David Luzzatto, who did not take Benamozegh into account at all. Luzzatto, however, who excelled as a philologist and linguist, saw philosophy, and even more so the kabbalah, as the products of a culture external to Judaism; useless, if not pernicious, for what he considered pure "Mosaism". As for Luzzatto's philosophy, expressed in Lezioni di teologia morale Israelitica (1862) and Lezioni di teologia dogmatica Israelitica (1864), it is quite elementary, especially if compared with the richness and complexity of Benamozegh's thought.

Elia Benamozegh entered into correspondence and argued with both Castelli and Luzzatto. In response to Luzzatto's criticism of kabbalah he wrote an entire book, in Hebrew, in which he argued the antiquity of the doctrine, while conceding that the writing of his classical texts such as the Zohar took place in the Middle Ages. With regard to "Mosaism", or rather the ethical monotheism professed by Luzzatto, he saw it as a naive, abstract and incomplete manifestation of authentic Judaism, which was not pure monotheism, but monotheism that admitted plurality as a necessary element for the correct concept of being; contrary to ancient religions, which were pluralist (polytheistic) in their public manifestation and unitary in their esoteric manifestation, Judaism presents itself at the popular level as simple monotheism, but opens to initiates the possibility or even the necessity of the existence of a plural reality. In the most sacred and secret part of the 
Sanctuary, Benamozegh recalls, there were two cherubs, a symbol of multiplicity, which, in addition, had partially human features.

These controversies are interesting as they demonstrate irreconcilable mentalities, one philological and positive, the other philosophical, of a philosophy that exalted the "poetic" language of the Zohar and was based on a doctrine, the kabbalah, considered at the time by almost all scholars as imaginative, not conceptually founded and, in short, as the worst product of Jewish culture. In this sense, Benamozegh can be regarded as a thinker outside the main stream of European thought: to the point that he openly formulates, in the context of the discussion on the immortality of the soul, the theory of metempsychosis, in line with the teaching of the kabbalah. Furthermore, the notion of resurrection is reinterpreted as the possibility of a human evolution that, going beyond the theories of Lyell and Darwin, reaches a more perfect humanity in the future, "on a regenerated earth": this is the "palingenesis" that we mentioned above.

Modern science was not seen as opposed to biblical and rabbinic texts or religious beliefs but in harmony with their ancient insights, concisely contained in a series of words and statements that must be interpreted. This new type of concordism between science and religion was unacceptable for the "oriental" religious circles, which Benamozegh-who was, we recall, of Moroccan origin-also had the ambition to address. The Aleppo rabbis, as we have seen, burned his commentary on the Torah, while the Jerusalem rabbis forbade its reading due to the excess guilt of "modernity".

Hypertraditionalist and, nevertheless, totally inserted in the philosophical, theological and scientific debate in the second half of the nineteenth century, Benamozegh did not see any true separation between the choices of the believer and those of the rationalist thinker. In this sense, he can be considered the product (probably the last one) of the development of the kabbalah in Italy, which had seen some of its most prestigious exponents of the early 1700s, such as Moshe Hayyim Luzzatto, support the need to expose the cabalistic doctrines to rational categories, making them clear and easily understandable; even though the sources of the esoteric tradition pertained to prophetic revelation and not to human argumentation.

As did the main exponents of the Jewish rationalism of the Middle Ages, especially Maimonides, Benamozegh sees a perfect coincidence between reason and traditional dogmatics:

My religious Belief is that of Orthodox Judaism, neither more nor less, because it is, if I do not mislead myself, that which best satisfies my reason, the only means that God has given us to discern the true from the false. [ ... ] Religion is like philosophy, it requires dialectical rigor, an inclination of abstraction, exquisite impartiality, an indefinite reasoning, sans peur et sans reproche. Religion, like science, have little to do with what is called common sense, and it is also for this reason that treating the second is beneficial to the first; and because finally blind faith can also be called a faithful blindness, and it is quite true what Rabbi Bachie said eight centuries ago: ${ }^{28}$ that one cannot be a true believer if he is not a prophet or a philosopher. This does not mean, however, that sentiment in religion should have no part whatsoever: only that it should be secondary and a substitute, and that only then the affection should light up when reason has enlightened it. It is the light that must become heat. ${ }^{29}$

Despite the coherence and depth of his Italian philosophical works and his Hebrew commentary on the Torah (which was, however, widespread in the "modern" Maghreb Jewish religious circles), Benamozegh's fame remains linked to the French works, Morale juive et morale chrétienne and Israël et l'Humanité. In the first book, Benamozegh actually provides one of Judaism's most brilliant defenses against the thesis of the superiority (and the overcoming) of Christian morality; the second-published and extensively reworked by his Christian disciple Aimé Pallière-contains the proposal of a universal religion, that is, of a Judaism which, while remaining particular and national, addresses the whole of humanity by proposing an exit from the serious religious crisis of time. 
Published several times, translated, and studied in recent times, Benamozegh finds it hard to find, in the history of Jewish thought and even less in that of Italian thought, the place that probably belongs to him for his coherence, strength and originality. If it cannot be ruled out that his style, which has declamatory tendencies, has harmed his reception (his tone has been considered more like that of a preacher than a systematic philosopher), it is undoubtedly due to his radically original position on some issues, and, furthermore, to the confluence of different worlds in his intellectual personality, that his reading has been, and still is, so contested (Guetta 2001). An authentic coherence of thought expressed through the use of tools from different cultural worlds can be wrongly taken as syncretism.

If, for Benamozegh, the truth of the kabbalah and its translatability into modern terms did not raise any doubts, modern and secularized readers have distanced themselves from these ideas, and postmodern ones cannot follow him in his passionate affirmations of the existence of an Absolute to which man and the world tend towards as an objective, infinite yet necessary. Nevertheless, it is precisely in this religious passion, served by an immense and varied culture, that Elia Benamozegh's most authentic and lively contribution can be found. Benamozegh was well aware of his culturally difficult situation, suspended between two worlds, as he wrote in a brilliant Hebrew prose in his apology addressed to the rabbis of Jerusalem:

Oh gentlemen, I will give you an example to describe my situation. An elderly man had two wives, one young and one old [ ... ]. He was turning gray, and the young woman tore off his white hair while the old woman tore off the black ones, so he would be similar to them: and he, poor fellow, suffered the consequences, because he remained bald on both sides.

As is my case: I considered faith and science as one thing, like two knights side by side, but some tell me: "Your religious fear is your stupidity", and others "Your science is vanity, a useless effort, your book is a rotten carrion". And I, poor fellow, am in the middle, [ ... ] from the waist up I belong to the devil, from the waist down to God.

For some I am a pious imbecile, for others a disbelieving heretic. One says: "He cannot be called a wise man, nor a researcher", and another says: "He is a cowherd, a sycamore farmer". ${ }^{30}$ On the one hand: "Europe is not his place, he should go to Jerusalem, to the mount of myrrh", and on the other hand: "May he not enter the sanctuary! He must remain outside, along with nonJewish scholars".

And I remain suspended in the air, neither disbeliever nor scribe, neither heretic nor believer, neither fool nor cabbalist, neither philosopher nor rabbi, [ . . ] neither assimilated nor faithful, neither Shammai nor Hillel, ${ }^{31}$ neither day, nor night" ${ }^{32}$

Funding: This research received no external funding.

Institutional Review Board Statement: Not applicable.

Informed Consent Statement: Not applicable.

Conflicts of Interest: The author declares no conflict of interest.

\section{Notes}

1 There were, of course some meaningful exceptions, such as the French historian of philosophy Adolphe Franck, the closest author to Benamozegh, who composed the valuable La Kabbale ou philosophie religieuse des Hébreux, Paris, Hachette, 1843, where Kabbalah was seen as a sort of rebellion against the commonplaces of exegesis. In his recent book Kabbalah Research in the Wissenschaft des Judentums (1820-1880): The Foundation of an Academic Discipline, Berlin, De Gruyter, 2019, George Y. Kohler has nuanced the negative judgment of Kabbalah among Jewish scholars of the 19th century E. Benamozegh, Em la-miqra, Livorno, by the author, 1862-1863.

2 E. Benamozegh, Morale juive et morale chrétienne, Paris, Kauffmann, 1867. English translation Jewish and Christian Ethics. With a Criticism of Mahomedism, San Francisco, 1873. 
Id., L'origine des dogmes chrétiens, Paris, in press, 2011.

Id., Teologia dogmatica e apologetica, Dio, Livorno, Vigo, 1877.

Id., Israël et l'humanité, Paris, Leroux, 1914. English translation by Maxwell Luria, New York, Paulist Press, 1995.

Id., Storia degli Esseni, Firenze, Le Monnier, 1865.

Id., "Spinoza et la kabbale", « Univers israélite», vol. XIX, 1864.

Teologia dogmatica e apologetica, op. cit., p. 144.

Benamozegh cites, in this regard, Gioberti's distinction, in his Protologia ("First science"), between legitimate and illegitimate anthropomorphism. See Vincenzo Gioberti, Della Protologia, Paris, Chamerot Librairie, 1857.

Bouluque, Another Modernity, op. cit., pp. 73-74.

On this topic, see F. V. Tommasi, L'analogia della persona in Edith Stein, Pisa/Roma, Fabrizio Serra Editore, 2012.

Moshe Idel identifies an idea of Yitzhaq Luria in Benamozegh's reading of berur as "natural selection". See M. Idel, "Kabbalah in Elijah Benamozegh's Thought", appendix to the English translation of Israel and Humanity, op. cit. The main source of benamozegh remains, nonetheless, the book of Zohar.

Intuition and reflection are typical themes of Gioberti's thought, see Della Protologia, op. cit. pp. 19-20.

Elia Benamozegh, "Gli attributi di Dio", unpublished part of the Teologia published posthumously in the journal Lux, 1 (1904), p. 26.

Ibid., p. 2.

Ibid., p. 4.

Teologia dogmatica e apologetica, op. cit., p. 84.

In the essay "Spinoza et la kabbale", in which Benamozegh proposes to consider the possibility of kabbalistic sources (in addition to those of medieval Jewish philosophy, of Descartes and of some eterodox Calvinist currents) as decisive for the formation of the Dutch philosopher's thought. It should be noted that Spinoza's thought was, during those years, at the center of the attention of philosophers (founder of modern idealism or of "dangerous" pantheism?) and of philosophy historians.

Ibid., p. 265.

E. Benamozegh, "L'immortalità dell'anima in Giobbe e nei Proverbi", Annuario di Studi Ebraici, Rome, Poligrafica Sabbadini, 1977, pp. 145-172. See in particular p. 164.

Eduard von Hartmann, Philosophie des Unbewussten, Berlin, Carl Duncker, 1869.

Teologia dogmatica e apologetica, op. cit., p. 93.

Ibid., p. 269.

During those years, the German Jew Moritz Lazarus founded the scientific study of the "psychology of peoples", the Volkspsychologie.

E. Benamozegh, "Spinoza et la Kabbale", op. cit., p. 38.

See L. Amoroso, Benamozegh e Vico, in A. Guetta (ed.), Per Elia Benamozegh, op. cit., pp. 187-206.

E. Benamozegh, Storia degli Esseni, op. cit., p. 34.

Bahya ibn Paquda, 11th century Andalusian Jewish writer, author of the famous ethical-philosophical treatise in Arabic Duties of the heart.

Teologia dogmatica e apologetica, op. cit., p. 277.

Amos 8:14.

Two masters of the Mishnah (the monument of the oral juridical tradition, 1st century AD), who gave rise to two systematically opposed schools.

E. Benamozegh, “Tzori Gil'ad”, in Kevod ha-Levanon, VIII (1871), No. 43, p. 352.

\section{References}

Guetta, Alessandro. 1998. Philosophie et Cabbale. Essai sur la Pensée d'Elie Benamozegh. Paris: L'Harmattan.

Guetta, Alessandro. 2001. Per Benamozegh. Atti del Convegno Internazionale sull'opera di Elia Benamozegh. Milan: Thàlassa De Pas.

Guetta, Alessandro. 2009. Philosophy and Kabbalah: Elijah Benamozegh and the Reconciliation of Western Thought and Jewish Esotericism. Revised and Augmented English Version, Collection «Contemporary Jewish Thought ». Albany: State University of New York (SUNY) Press.

Morselli, Marco Cassuto, and Gabriella Maestri. 2017. Elia Benamozegh Nostro Contemporaneo. Genova: Marietti. 